\title{
Evaluation of English Teaching Effect Based on the Theory of Multiple Intelligences
}

\author{
https://doi.org/10.3991/ijet.v16i22.26881 \\ Jiangyong Zhao $^{(\bowtie)}$, Kun Liang, Yanan Hao \\ Shijiazhuang University of Applied Technology, Shijiazhuang, China \\ monster6788@sina.com.cn
}

\begin{abstract}
The new curriculum reform defines the all-round development of students as the main goal of English teaching. This paper applied the theory of multiple intelligences to English teaching, and evaluated the effect of English teaching based on this theory. Firstly, a survey was conducted in the colleges of a Chinese province, the current state of college English teaching was analyzed, and the results revealed a few problems in college English teaching, such as the lack of diversity in teaching modes and effects, and the weak interest of students in English learning. Based on the survey results, the authors specified the flow of English teaching design and the evaluation system of teaching effect, drawing on the theory of multiple intelligences. Then, an empirical analysis was carried out to comparatively examine our evaluation method for English teaching effect. The results indicated that our method can practically and effectively enhance students' interest and motivation for English learning, and improve the quality of English teaching. The research results provided a reference for the reform of college English teaching and the all-round development of students.
\end{abstract}

Keywords - theory of multiple intelligences, current state of English teaching, teaching design process, evaluation of teaching effect

\section{$1 \quad$ Introduction}

As one of the lingua franca, the teaching of English language has occupied an important position in the education system of China; now as the international exchanges and cross-country cooperation activities are getting closer and more frequent, the Chinese society has imposed higher requirements on the talents' ability to use the English language, in such context, the traditional English teaching mode and evaluation system can no longer adapt to the needs of the times, and how to trigger students' interests in English learning, how to improve the quality and effectiveness of English teaching, and how to enhance students' ability to use English comprehensively have become issues that require the college English teaching reform to give prompt solutions.

Foreign scholars have accumulated rich experience in the theory and practice research of the learning of second language. Listening, speaking, reading, writing, and translating are defined as the five basic language skills [1]. Therefore, in China, field 
scholars have conducted various theoretical and empirical studies on the modes, methods, effect, influencing factors, evaluation indicators, and evaluation methods of English teaching from perspectives of these basic language skills [2], however, until now no unified viewpoint has been formed yet, and some research directly introduces the research results of foreign studies, which are not applicable to the actual conditions of Chinese English-learners [3], and this has resulted in the situation that the effect of English teaching in Chinese colleges and universities is not satisfactory. In 1983, American psychologist Gardner proposed the theory of multiple intelligences, he pointed out that the traditional definition of talents and intelligences is one-sided and could not reflect the true abilities of individuals [4]. The theory of multiple intelligences believes that everyone has different intelligences; different people may have different intelligence combinations in different time periods; intelligences are not static, and everyone can change and expand their intelligences through efforts [5]. Education shouldn't treat all students alike, but should explore each student's talents and cultivate them, through education, everyone should be able to exert his/her greatest potential and obtain greatest possible achievement [6]. The proposal of the theory of multiple intelligences has provided new enlightenment and development direction for college education, and we should apply diversified teaching tools and evaluation methods to stimulate students' learning potential, help them build self-confidence, and enable them to find ways to achieve self-actualization according to their own advantages [7].

Based on an investigation of the current state of English teaching in Chinese colleges, this paper drew on the theory of multiple intelligences and designed a teaching evaluation method that is suitable for the teaching practice in Chinese colleges, in the hopes of offering a useful reference for promoting the English teaching reform in China.

\section{Investigation and analysis of the current state of English teaching in colleges}

To design a teaching evaluation method that is suitable for the actual conditions of English teaching and student development level in China, it's a necessary work to conduct an in-depth investigation on the current state of English teaching in Chinese colleges, for this purpose, this paper designed a Questionnaire on Current State of College English Teaching [8] which consisted of two parts: one part for students and one part for teachers. Then several college teachers and students were taken as respondents and invited to participate in the survey, Table 1 gives the basic information of questionnaire distribution and collection. 
Paper-Evaluation of English Teaching Effect Based on the Theory of Multiple Intelligences

Table 1. Information about questionnaire distribution and collection

\begin{tabular}{|l|c|c|c|c|}
\hline Respondent & Job title & $\begin{array}{c}\text { Number of question- } \\
\text { naires distributed }\end{array}$ & $\begin{array}{c}\text { Number of valid questionnaires } \\
\text { returned }\end{array}$ & $\begin{array}{c}\text { Efficient } \\
\text { rate (\%) }\end{array}$ \\
\hline \multirow{4}{*}{ Teacher } & Teaching assistant & 15 & 14 & 93.3 \\
\cline { 2 - 5 } & Lecturer & 15 & 14 & 93.3 \\
\cline { 2 - 5 } & Associate Professor & 15 & 15 & 100 \\
\cline { 2 - 5 } & Professor & 15 & 15 & 100 \\
\hline Total & & 60 & 58 & 96.7 \\
\hline \multirow{2}{*}{ Respondent } & Grade & $\begin{array}{c}\text { Number of question- } \\
\text { naires distributed }\end{array}$ & $\begin{array}{c}\text { Number of valid questionnaires } \\
\text { returned }\end{array}$ & $\begin{array}{c}\text { Efficient } \\
\text { rate (\%) }\end{array}$ \\
\hline \multirow{4}{*}{ Student } & Freshman & 200 & 198 & 99 \\
\cline { 2 - 6 } & Sophomore & 200 & 199 & 99.5 \\
\cline { 2 - 6 } & Junior & 200 & 197 & 98.5 \\
\cline { 2 - 6 } & Senior & 200 & 195 & 97.5 \\
\hline Total & & 800 & 789 & 98.6 \\
\hline
\end{tabular}

\subsection{Current state of teachers' teaching}

Figure 1 shows the survey results of the key content taught by teachers during English teaching. According to the statistics, most teachers emphasize on vocabulary, grammar, and reading comprehension, while ignoring speaking, listening, and developing students' interests in English. Further investigation also revealed that, most English teachers still adopt the traditional classroom lecturing method, although some teachers use multimedia in teaching or teach their lessons in English learning labs equipped with computers and other equipment, few of them would interact with students, failing to let students play the dominant role in the English class.

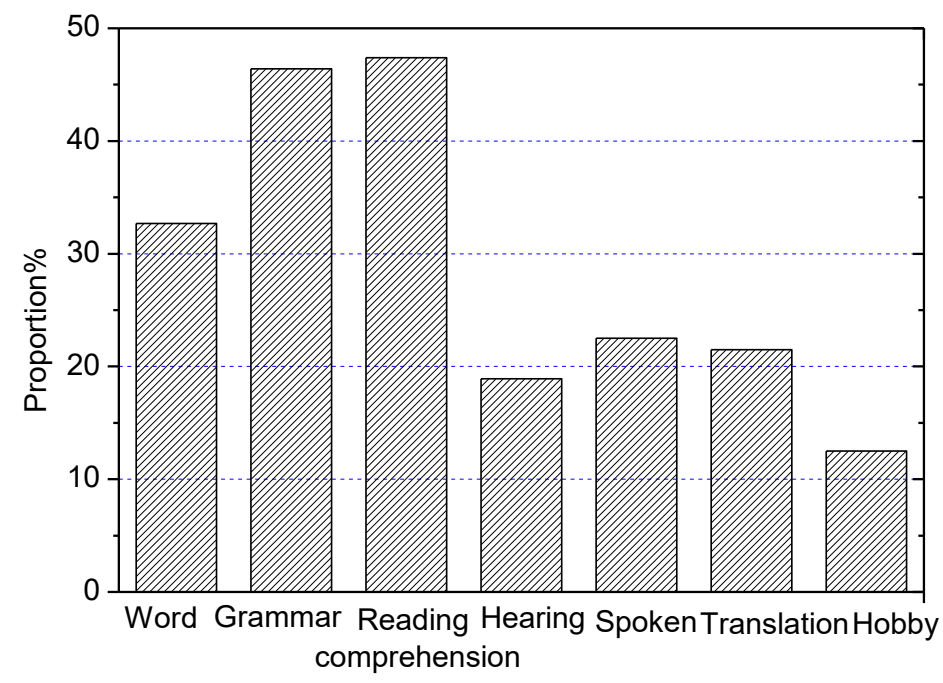

Fig. 1. Key content of English teaching 


\subsection{Current state of students' learning}

Figure 2 shows the survey results of students' English learning motivations. As can be seen from the statistics, students' English learning interest decreases with the increase of their grade, overall speaking, their English learning interest is not high, only less than $20 \%$ of them express an interest in English learning, while for most of them, they learn English just to cope with grade exams such as CET-4 and CET-6 (CET stands for College English Test), some learn English for the purposes of taking the postgraduate entrance examination or hunting for a job, and a small proportion of the students learn English in order to prepare themselves for studying abroad in the future. There're also some differences in the English learning motivations of students from different grades, for example, freshman and sophomore students learn English mainly to pass the CET- 4 and CET- 6 exams, while juniors and seniors aim to prepare for postgraduate exams.

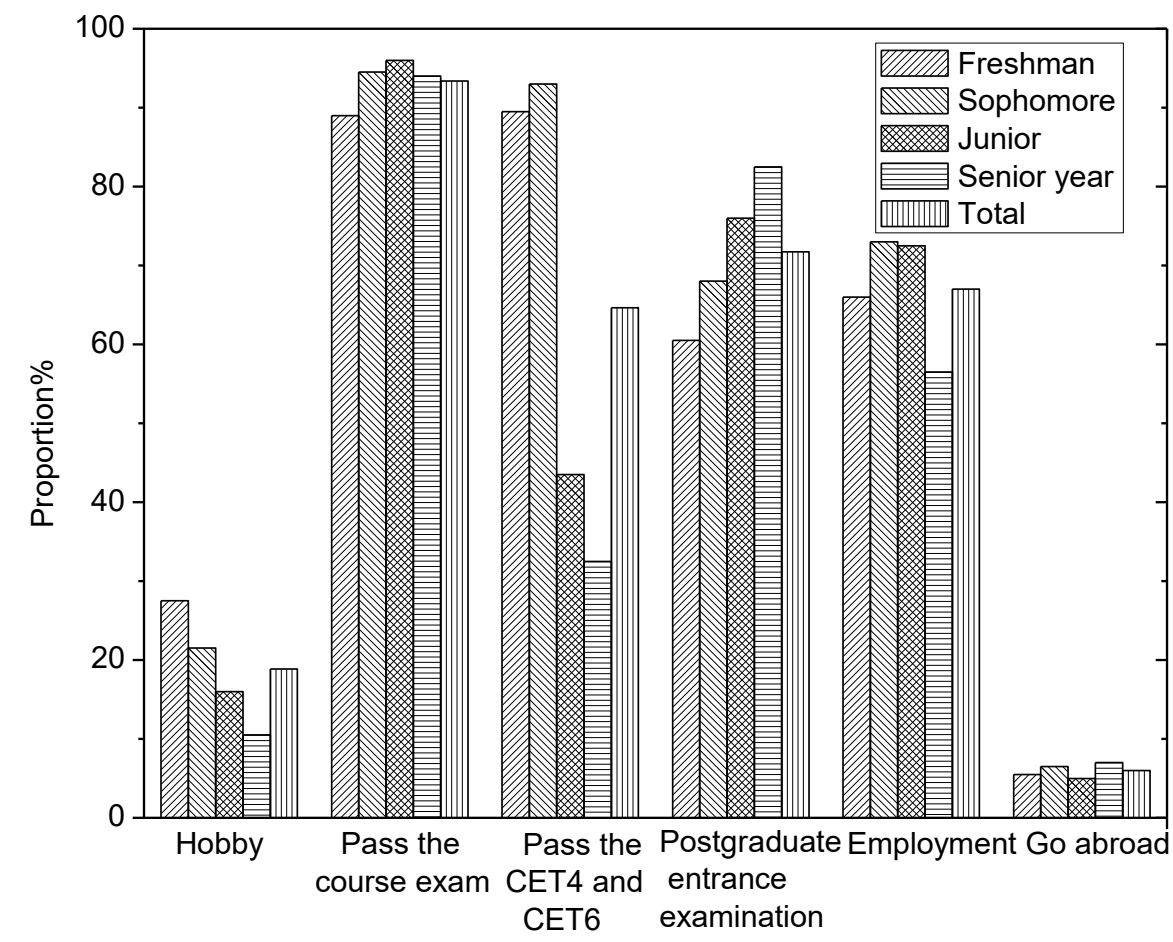

Fig. 2. Students' English learning motivations

Figure 3 shows the survey results of students' satisfaction with English teaching. According to statistics, the overall satisfaction degree of students for English teaching is not high, most students think the English teaching level is just average; interview with the students also suggests that students generally think the English class is dull and boring, teachers just announce the subject according to the content of the textbook, and there's few interactions between teachers and students. 


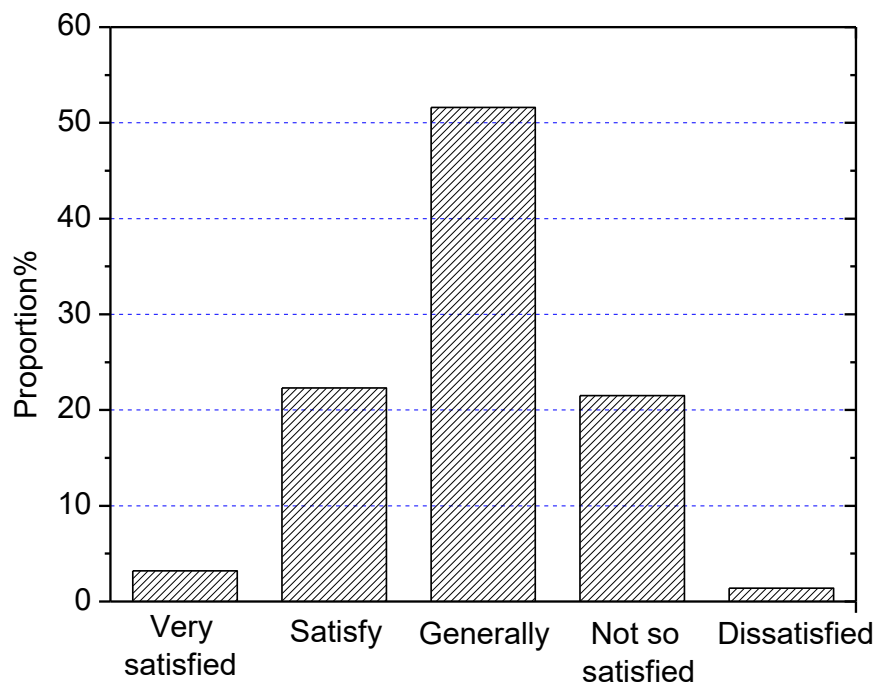

Fig. 3. Students' satisfaction with English teaching

\subsection{Current state of teaching effect evaluation methods}

Through investigation, it is found that currently there're mainly two evaluation methods of college English teaching effect, one is the CET-4 and CET-6 exams, another is the semester-end English course exams held by the schools. The semester-end exams generally include questions such as listening, single choice, multiple choice, reading comprehension, cloze, error correction, translation, and writing, and there's no oral English content. Student scores are usually composed of two parts: usual scores and semester-end scores. Table 2 shows the composition of student scores in college English class.

Table 2. Composition of student scores in college English class

\begin{tabular}{|l|c|c|}
\hline \multicolumn{3}{|c|}{ Total score: 100 } \\
\hline \multicolumn{2}{|c|}{ Usual scores: 100 (50\%) } & Semester-end scores: 100 (50\%) \\
\hline Attendance: 20 & Class Notes:20 & Written examination: 100 \\
\hline Classroom performance: 20 & Operation: 40 & \\
\hline
\end{tabular}

Figure 4 shows the survey results of whether teachers and students think that the current teaching effect evaluation methods are helpful for enhancing students' comprehensive English ability, according to statistics, most teachers and students think that the current teaching effect evaluation methods only have an average effect or do not have much effects on enhancing students' comprehensive English ability. Interview with teachers and students tells us that the teachers and students generally believe that these assessment methods have ignored the individual differences of students and their Eng- 
lish learning process, which is very detrimental to the cultivation of students' comprehensive ability (including teamwork ability, and comprehensive English language skills, etc.) and to the intelligence development of individual students.

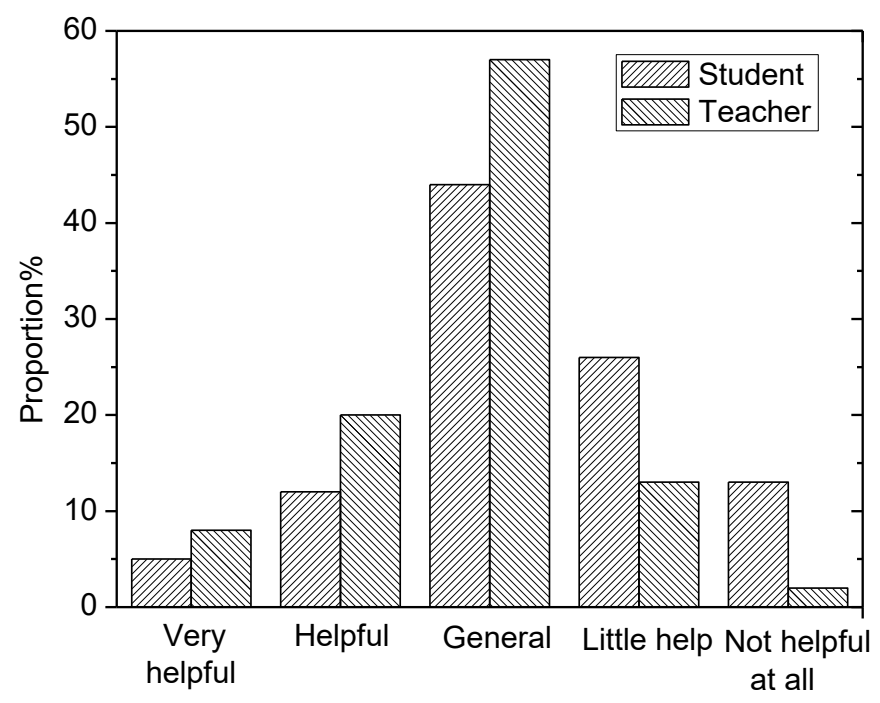

Fig. 4. Whether teachers and students think that the current teaching effect evaluation methods are helpful for enhancing students' comprehensive English ability

\section{Evaluation of English teaching effect based on the theory of multiple intelligences}

The survey results listed in above paragraphs have revealed a few problems in college English teaching, such as the single teaching mode and teaching effect evaluation method, and students' generally lack interest in English learning, etc., and these are not good for cultivating students' comprehensive language ability and developing their individual intelligence. In view of these situations, this paper combined the theory of multiple intelligences with college English teaching, in the hopes of designing an English teaching effect evaluation method that is conductive to students' English learning and overall development.

\subsection{About the theory of multiple intelligences}

With the progress of human society, more and higher requirements have been proposed for talents, and people's definition of talents and educational concepts should change in accordance with the development of the times. In his theory of multiple intelligences, Garnard holds that every person has at least eight kinds of intelligence, and each kind of intelligence does not exist alone; for different people, their development levels of the eight kinds of intelligence are different; even for a person, the development 
levels of the eight kinds of intelligence vary in different life stages. Therefore, through training and hard work, everyone can exert these eight intelligences to a relatively high level. Figure 5 shows the model of the multiple intelligence theory [9]. The essence of education is to cultivate the social activities of people, colleges and universities are the cradle for cultivating talents, so the college English teaching should learn from the theory of multiple intelligences, and use diversified teaching methods and evaluation methods to continuously tap the potential of students, teach them in accordance with their aptitude, and promote them to develop in an all-round way [10].

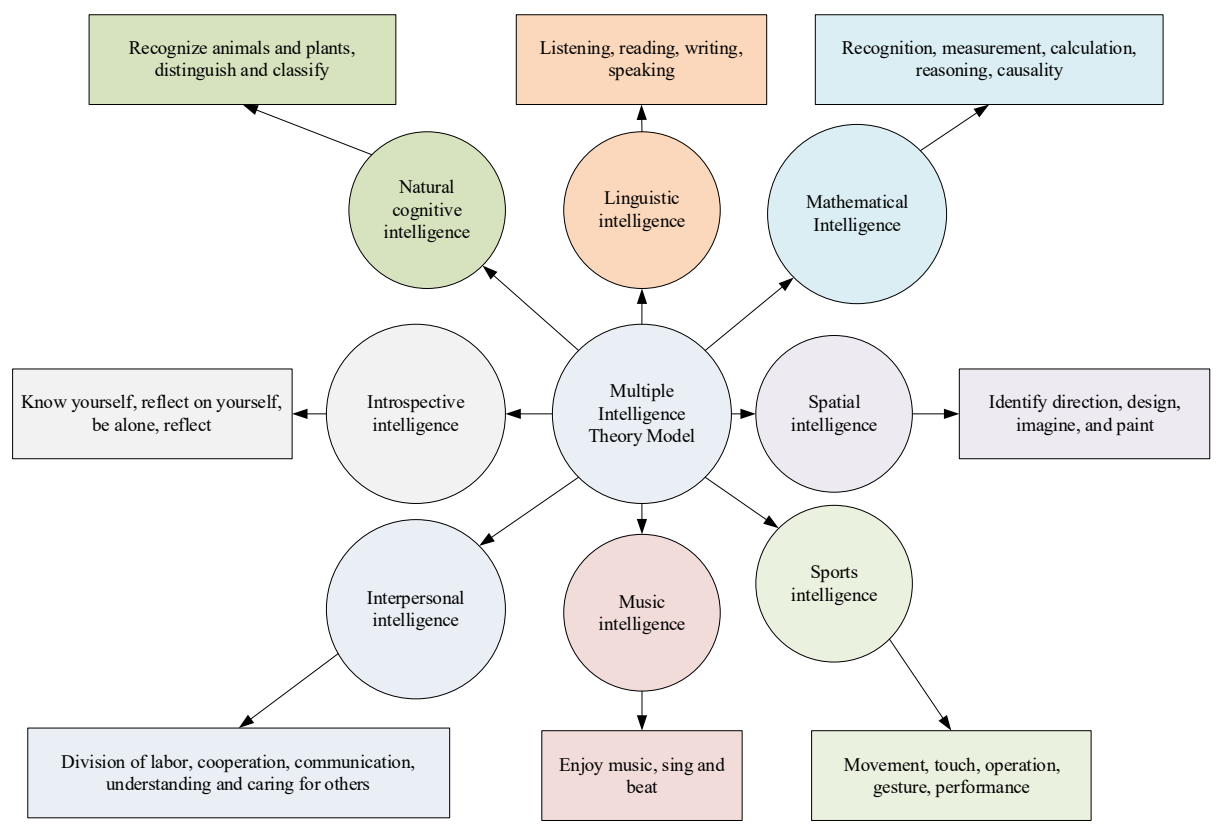

Fig. 5. Model of the multiple intelligence theory

\subsection{Design of English teaching based on the theory of multiple intelligences}

Before English teaching, the English teachers usually need to design the teaching works; teaching design contains three parts, the specific content is given in Figure 6 [11]. AT first, teachers need to analyze students' personality, learning motivations, learning interests, and other learning situations; then, after figuring out the learning features and requirements of students, teachers need to analyze and research the teaching content based on the syllabus and curriculum standards; on this basis, the designed English course needs to meet the teaching goals, and teachers need to design the specific teaching strategies, and the specific teaching techniques and activities for different teaching contents; in addition, scientific and reasonable teaching evaluation methods and standards should be designed to ensure that the teaching activities could be carried out smoothly and the teaching goals could be achieved [12]. 
Under the instruction of the theory of multiple intelligences, the college English teaching should pay special attention to introducing more teacher-student interaction links based on the traditional lecturing mode; according to the specific teaching content and the personality and advantages of different students, teachers can reasonably make use of the multimedia technologies and forms such as audios, videos, and animations to display the learning content to students in a more intuitive way, so as to motive their learning initiative; also, various classroom teaching forms, such as English speech contests, English sitcoms, English debate contests, and English song contests, could be applied to enrich the English class and give full play to students' dominant role in class, in this way, every student could find fun in English class, they can exert their own advantages, and develop all their intelligences [13].

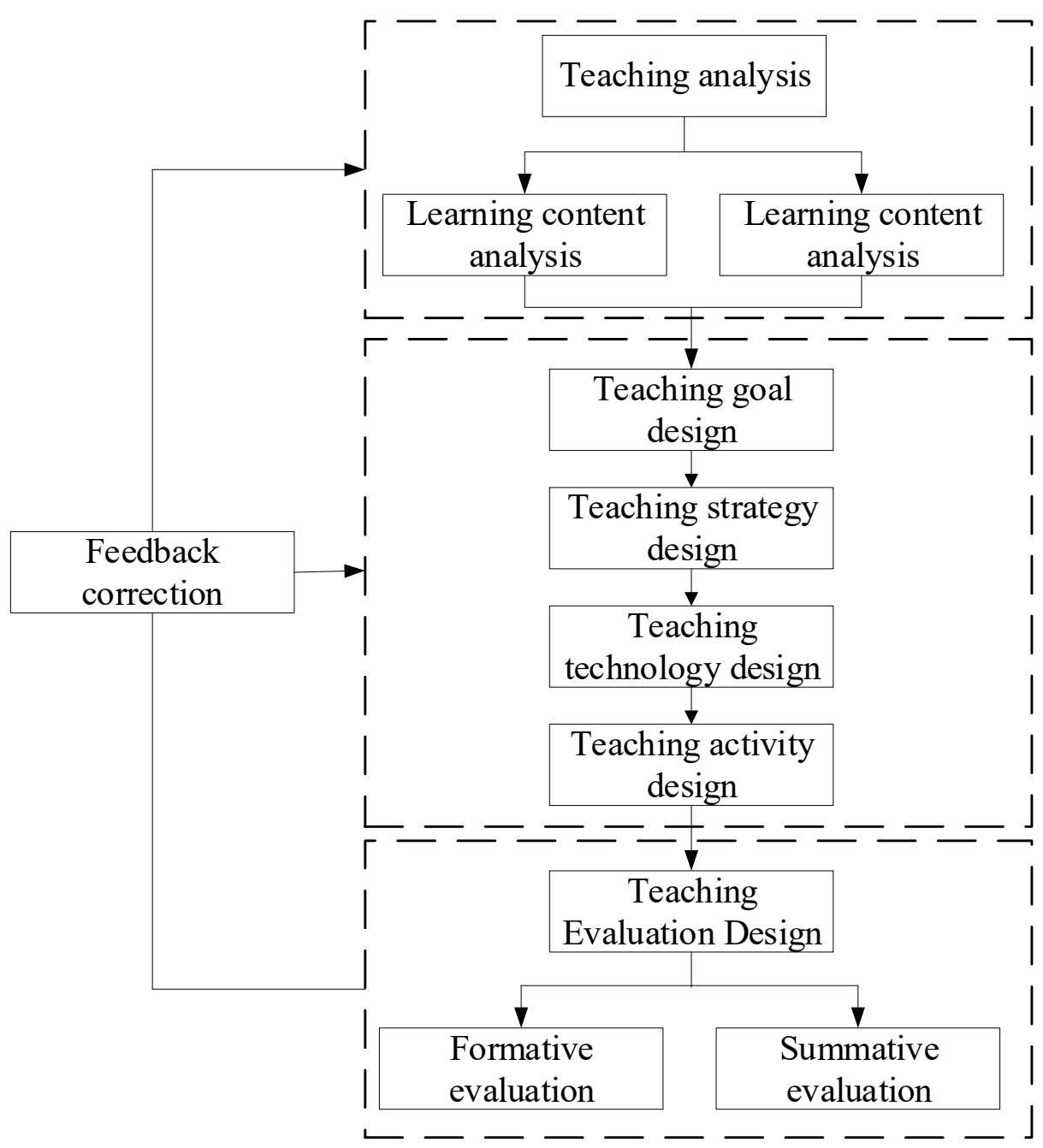

Fig. 6. English teaching design process 


\subsection{Design of English teaching effect evaluation method based on the theory of multiple intelligences}

Under the instruction of the theory of multiple intelligences, the evaluation methods of English teaching effect should be diversified in three aspects: evaluation object, evaluation content, and evaluation method [14]. Besides the traditional summative-type evaluation, the student evaluation should introduce the process-based evaluation, Table 3 gives the process-based English teaching effect evaluation table designed based on the theory of multiple intelligences in this paper [15]. Such process-based evaluation mainly focuses on aspects such as the students' learning attitude, teamwork, and advancement; teachers, the student being evaluated, and peers of the student being evaluated jointly finish the evaluation, and the evaluation results will be recorded in the personal file to facilitate the student to make comparisons according to his/her own conditions. Table 4 shows the summative evaluation form of English teaching effect based on the theory of multiple intelligences [16]. The summative evaluation is divided into two parts: the oral test and the written test. In the oral test, students draw a test topic and give free speech based on the topic, teachers give score according to certain evaluation standards. The final score of student is composed of the process-based evaluation score (50\%) and the summative evaluation score $(50 \%)$.

Table 3. Process-based evaluation form of English teaching effect

\begin{tabular}{|c|c|c|c|c|c|}
\hline \multirow{2}{*}{ Comment content } & \multicolumn{5}{|c|}{ Evaluation standard } \\
\hline & Excellent (90-100) & Good (89-70) & \multicolumn{2}{|c|}{ Moderate (59-69) } & Poor (0-59) \\
\hline \multicolumn{6}{|l|}{ Active learning } \\
\hline \multicolumn{6}{|l|}{ Good at finding problems } \\
\hline \multicolumn{6}{|l|}{$\begin{array}{l}\text { Complete individual division of } \\
\text { labor }\end{array}$} \\
\hline \multicolumn{6}{|l|}{ Participate in group discussions } \\
\hline \multicolumn{6}{|l|}{ Self-reflection } \\
\hline \multicolumn{6}{|l|}{ Better than before } \\
\hline \multirow[b]{2}{*}{ Comment content } & \multicolumn{5}{|c|}{ Evaluation subject } \\
\hline & $\begin{array}{l}\text { Self-evaluation } \\
(20 \%)\end{array}$ & \multicolumn{2}{|c|}{$\begin{array}{l}\text { Mutual evaluation } \\
\quad(20 \%)\end{array}$} & \multicolumn{2}{|c|}{$\begin{array}{c}\text { Teacher evaluation } \\
(60 \%)\end{array}$} \\
\hline \multicolumn{6}{|l|}{ Active learning } \\
\hline \multicolumn{6}{|l|}{ Good at finding problems } \\
\hline \multicolumn{6}{|l|}{$\begin{array}{l}\text { Complete individual division of } \\
\text { labor }\end{array}$} \\
\hline \multicolumn{6}{|l|}{ Participate in group discussions } \\
\hline \multicolumn{6}{|l|}{ Self-reflection } \\
\hline Better than before & & & & & \\
\hline
\end{tabular}


Table 4. Summative evaluation form of English teaching effect

\begin{tabular}{|c|c|c|c|c|c|c|}
\hline \multirow{2}{*}{ Project } & \multirow{2}{*}{ Comment content } & \multicolumn{4}{|c|}{ Evaluation standard } & \multirow{2}{*}{$\begin{array}{c}\begin{array}{c}\text { Evaluation } \\
\text { subject }\end{array} \\
\begin{array}{c}\text { Teacher } \\
\text { evaluation }\end{array}\end{array}$} \\
\hline & & $\begin{array}{c}\text { Excellent } \\
(90-100)\end{array}$ & $\begin{array}{c}\text { Good } \\
(89-70)\end{array}$ & $\begin{array}{c}\text { Moderate } \\
(59-69)\end{array}$ & $\begin{array}{c}\text { Poor (0- } \\
59)\end{array}$ & \\
\hline \multirow{4}{*}{$\begin{array}{l}\text { Oral expression } \\
(30 \%)\end{array}$} & Accurate intonation & & & & & \\
\hline & $\begin{array}{l}\text { Fluent language and } \\
\text { clear voice }\end{array}$ & & & & & \\
\hline & $\begin{array}{c}\text { Grammatically accurate } \\
\text { and complete }\end{array}$ & & & & & \\
\hline & Focus on the theme & & & & & \\
\hline $\begin{array}{l}\text { Final test } \\
(70 \%)\end{array}$ & Written examination & \multicolumn{4}{|c|}{ Scoring according to test paper requirements } & \\
\hline
\end{tabular}

\subsection{Empirical analysis of English teaching effect based on the theory of multiple intelligences}

To verify the effectiveness of the evaluation method proposed in this paper, nonEnglish majors from two sophomore classes in a college were selected as research objects to perform a comparative experiment; the two classes were taught by a same teacher, one class was taken as the experimental group, and the English teaching design and teaching effect valuation method proposed in this paper were adopted for this class; the other class was taken as the control group, and the traditional English teaching mode and teaching effect evaluation method were adopted for this class. Each of the class had 45 students, and the experiment lasted for one semester. Our research team designed a Questionnaire on College Students' Learning Situation and a Questionnaire on Multiple Intelligences of College Students [17] for the experiment to investigate and analyze the situations of English learning and multiple intelligences of students in the experimental group and the control group before and after the experiment.

Situations of students' English learning before and after the experiment. Figure 7 shows the survey results of the two groups of students' interests in English class and teaching activities before and after the experiment. As can be seen from the figure, before the experiment, students from both groups generally expressed a lack of interest in English class, after the experiment, this situation didn't change much in the control group, while in the experimental group, students' interests in English class had improved, the proportions of students who expressed very interested and interested increased from the original $6 \%$ and $15 \%$ to the present $10 \%$ and $32 \%$; and the proportions of students who expressed an average interest, not very interested, and not interested decreased from the original $58 \%, 7 \%$, and $14 \%$ to the present $48 \%, 4 \%$, and $6 \%$, respectively, indicating that the proposed English teaching design and teaching effect evaluation method designed based on the theory of multiple intelligences can improve students' interests in English learning to a certain extent. 


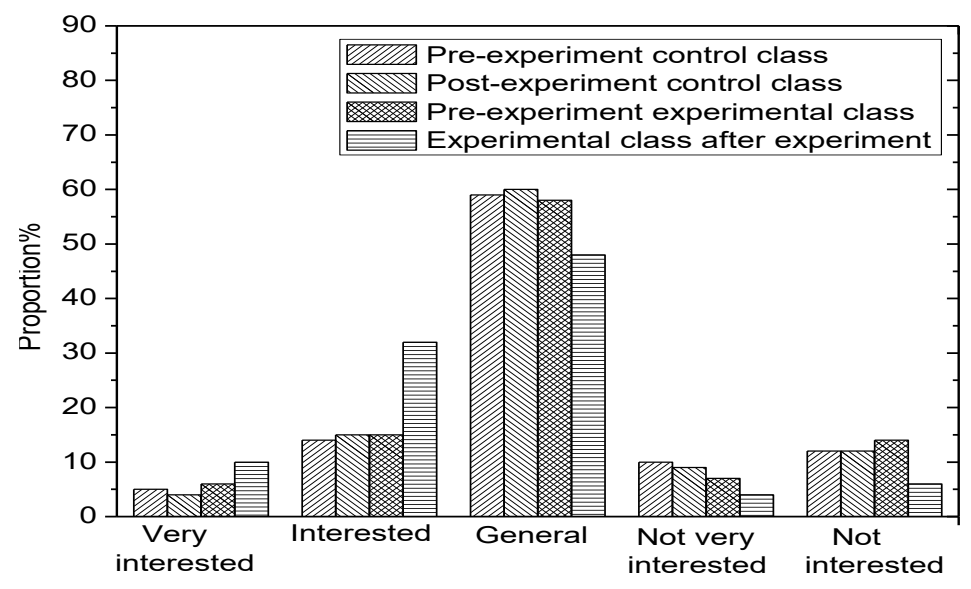

Fig. 7. Students' interests in English class and teaching activities before and after the experiment

1. Situations of students' multiple intelligences before and after the experiment.

Table 5 shows the survey results of the multiple intelligences of students in the two groups before and after the experiment. Figure 8 shows the survey results of the experimental group before and after the experiment, according to Table 5 and Figure 8, before the experiment, there're not much differences in the average scores of the multiple intelligences of students in the experimental group and in the control group; after the experiment, the average scores of control group students didn't show obvious changes, while the average scores of experimental group students increased by varying degrees, indicating that the teaching effect evaluation method designed based on the theory of multiple intelligences can promote the development and improvement of students' multiple intelligences.

Table 5. Survey results of multiple intelligences of students in the two groups before and after the experiment

\begin{tabular}{|l|c|c|c|c|}
\hline \multirow{2}{*}{ Intelligence classification } & \multicolumn{2}{|c|}{ Before the experiment } & \multicolumn{2}{c|}{ After the experiment } \\
\cline { 2 - 5 } & $\begin{array}{c}\text { Experimental } \\
\text { group }\end{array}$ & $\begin{array}{c}\text { Control } \\
\text { group }\end{array}$ & $\begin{array}{c}\text { Experimental } \\
\text { group }\end{array}$ & $\begin{array}{c}\text { Control } \\
\text { group }\end{array}$ \\
\hline Linguistic intelligence (A) & 26.3 & 26.1 & 26.4 & 30.1 \\
\hline Mathematical intelligence (B) & 28.4 & 27.9 & 28.2 & 33.5 \\
\hline Spatial intelligence (C) & 28.5 & 28.1 & 28.6 & 32.8 \\
\hline Sports intelligence (D) & 29.5 & 28.9 & 29.1 & 30.1 \\
\hline Music intelligence (E) & 31.4 & 31.6 & 31.7 & 34.4 \\
\hline Interpersonal intelligence (F) & 29.2 & 28.9 & 29.5 & 35.8 \\
\hline Introspective intelligence (G) & 28.8 & 29.1 & 29.2 & 32.7 \\
\hline Natural cognitive intelligence (H) & 27.5 & 27.8 & 27.5 & 28.2 \\
\hline
\end{tabular}




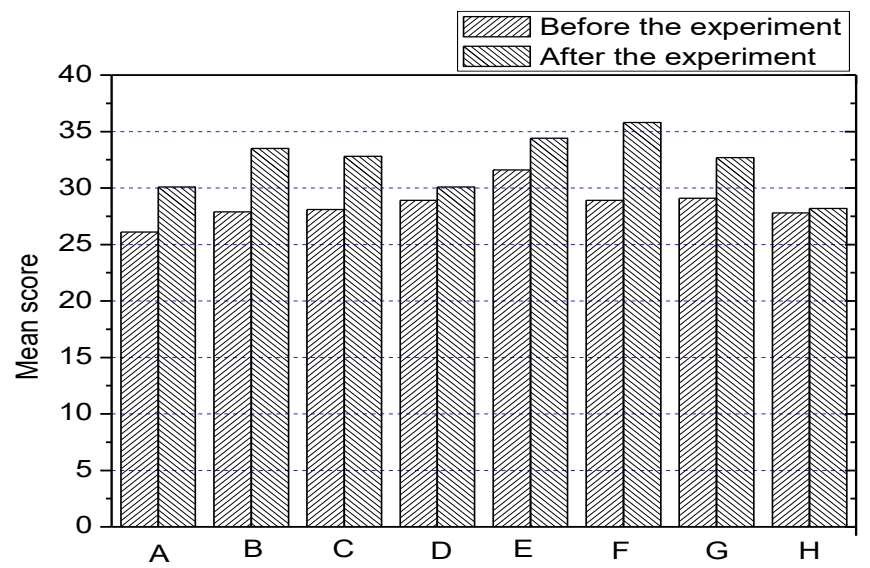

Fig. 8. Survey results of multiple intelligences of experimental group students before and after the experiment

\section{Conclusions}

The theory of multiple intelligences advocates diversified evaluation methods and it provides a theoretical basis for teachers to give comprehensive and objective evaluations to students. This paper studied the English teaching effect evaluation based on this theory and obtained following conclusions:

1. From the three perspectives of teacher, student, and teaching effect evaluation, this study investigated the current state of college English teaching and found out a few problems with it, such as the lack of diversity in teaching modes and evaluation methods, and the weak interest of students in English learning.

2. Based on survey results, this paper combined the theory of multiple intelligences with English teaching, analyzed the flow of English teaching design, and designed a college English teaching effect evaluation method based on the theory of multiple intelligences.

3. This paper employed empirical analysis to study the effectiveness of the proposed English teaching design and English teaching effect evaluation method based on the theory of multiple intelligences, and the experimental results proved that the proposed method can effectively improve students' interests in English learning, and promote the development of their multiple intelligences to a certain extent.

\section{$5 \quad$ References}

[1] Payne, D.A., Hobbs, A.M. (1979). The effect of college course evaluation feedback on instructor and student perceptions of instructional climate and effectiveness. Higher Education, 8(5): 525-533. https://doi.org/10.1007/bf00139792 
[2] Gardner, H., Hatch, T. (1989). Educational implications of the theory of multiple intelligences. Educational researcher, 18(8): 4-10. https://doi.org/10.3102/0013189x018008004

[3] Gardner, H. (2004). Audiences for the theory of multiple intelligences. Teachers College Record, 106(1): 212-220. https://doi.org/10.1111/j.1467-9620.2004.00329.x

[4] Ik, D., Tarm, K. (2009). The effects of the cooperative learning method supported by multiple intelligence theory on Turkish elementary students' mathematics achievement. Asia Pacific Education Review, 10(4): 465-474. https://doi.org/10.1007/s12564-009-9049-5

[5] Haley, M.H. (2010). Understanding learner-centered instruction from the persdective of multiple intelligences. Foreign Language Annals, 34 (4): 355-367 https://doi.org/10.1111/j. 1944-9720.2001.tb02068.x

[6] Barrington, E. (2004). Teaching to student diversity in higher education: how multiple intelligence theory can help. Teaching in Higher Education, 9(4): 421-434. https://doi.org/ $\underline{10.1080 / 1356251042000252363}$

[7] Li, X. (2019). Characteristics and rules of college English education based on cognitive process simulation. Cognitive Systems Research, 57: 11-19. https://doi.org/10.1016/ j.cogsys.2018.09.014

[8] Lara-Alecio, R., Tong, F., Irby, B.J., Guerrero, C., Huerta, M., Fan, Y. (2012). The effect of an instructional intervention on middle school English learners' science and English reading achievement. Journal of Research in Science Teaching, 49(8): 987-1011. https://doi.org/ $10.1002 /$ tea. 21031

[9] Cerruti, C. (2013). Building a functional multiple intelligences theory to advance educational neuroscience. Frontiers in Psychology, 4: 950. https://doi.org/10.3389/ fpsyg.2013.00950

[10] Gardner, H. (2004). Audiences for the theory of multiple intelligences. Teachers College Record, 106(1): 212-220. https://doi.org/10.1111/j.1467-9620.2004.00329.x

[11] Shearer, C.B., Luzzo, D. A. (2011). Exploring the application of multiple intelligences theory to career counseling. Career Development Quarterly, 58 (1): 3-13. https://doi.org/ $\underline{10.1002 / j .2161-0045.2009 . t b 00169 . x}$

[12] Jr, T. (1984). Review of frames of mind: The theory of multiple intelligences. American Journal of Orthopsychiatry, 54(3): 506. https://doi.org/10.1111/j.1939-0025.1984.tb01522.x

[13] Yang, W.W. (2009). Evaluation of teacher induction practices in a US university English language program: Towards useful evaluation. Language Teaching Research, 13(1): 77-98. https://doi.org/10.1177/1362168808095524

[14] Hearne, D., Stone, S. (1995). Multiple intelligences and underachievement: Lessons from individuals with learning disabilities. Journal of Learning Disabilities, 28(7): 439-448. https://doi.org/10.1177/002221949502800707

[15] Prodromou, L. (1995). The backwash effect: From testing to teaching. ELT Journal, 49(1): 13-25. https://doi.org/10.1093/elt/49.1.13

[16] Smith, C. (2006). Multiple cultures, multiple intelligences: applying cognitive theory to usability of digital libraries. Libri, 56(4): 227-238. https://doi.org/10.1515/libr.2006.227

[17] Motherwell, R. (1957). Linguistic science and the teaching of English. Inglis lectures in secondary education, 1954by henry lee smith. International Journal of American Linguistics, 23(1): 50-52. https://doi.org/10.1086/464390

\section{Authors}

Jiangyong Zhao is an associate professor working in the Department of Public Foreign Language in Shijiazhuang University of Applied Technology, China. His research 
interests include English competitions and teaching methodology. Three papers are published and 3 text books are published.

Liang Kun is a lecturer and working on Department of Public Foreign Languages of Shi jiazhuang University of Applied Technology, Hebei, China. She graduated from Hebei Normal University and the research interests is the teaching method of higher vocational. Since she got the lecturer, she has published more than eight papers and four books (Email: liangkun84130@163.com).

Yanan Hao is an associate professor working on English teaching in the School of Shijiazhuang University of Applied Technology, China. She graduated from the University of Waikato in New Zealand. She has been working in English teaching after graduation. Her research interests include Teaching Methods and Second Language Acquisition. She has conducted and participated in 5 research projects, and published 7 papers (Email: yananhao2021@126.com).

Article submitted 2021-09-12. Resubmitted 2021-10-12. Final acceptance 2021-10-12. Final version published as submitted by the authors. 